\title{
Cell-in-cell structures in BxPC3 pancreatic cancer cell line are the result of entosis
}

\author{
Magdalena Kowalczyk¹, Agnieszka Sarnecka1, Izabela Młynarczuk-Biały , Agnieszka Milik
}

1- Medical University of Warsaw, The Department of Histology and Embryology, Center of Biostructure Research 02-004 Warsaw, Chałubińskiego Street 5

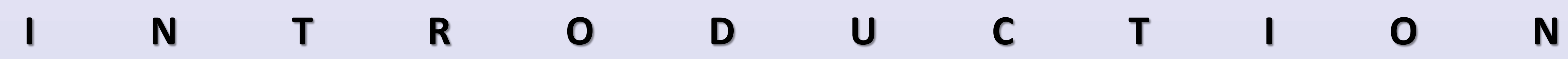

Entosis is a process which occurs between two epithelial cells after losing their connection to the basement membrane. It starts with activating Rho kinase pathway in one cell. Then, this cell forms adherens junction with another detached cell and actively invades into it to create cell-in-cell structure. The inner cell preserves its morphology and maintains proper mitochondrial potential while being inside another cell.

As a result of entosis the inner cell may undergo lysosomal degradation, mitotic division or leaving the outer cell with no harmful effects. Two last options prove that the condition of inner cell is quite good. Entosis was named in 2007 and still needs better molecular characteristics. Entosis was observed in physiological cells (e.g. in breast epithelial cells) and in pathological cases (for example in breast epithelial cancer).

Cannibalism is a process in which one tumor cell engulfs another cell: tumor cell or cell of the immune system (lymphocyte, neutrophile, etc). It ends in lysosomal degradation of engulfed cell. These phenomenon was described in different human tumors.

\section{A T E R I A L S A N D M M T H O D S}

- culture of BxPC3 (ATCC) cells (cell line of pancreatic cancer- pancreas adenocarcinoma) was used in all experiments

- before using confocal microscopy cells were stained with following stains: the nucleus was stained blue with Hoechst,

the cytoplasm was stained green with CFDA-SE cell tracker kit, actin filaments were stained red with Phalloidin

before using light microscope cells were fixed with paraformaldehyde and stained with hematoxylin and eosin

- cells for electron microscope were grown on special thermanox plastic coverslips, then stained with glutaradehyde and contrasted with osmium tetroxide

- cells were incubated with Rho kinase inhibitor (Sigma-Aldrich, 0,1 $\mu \mathrm{M}, 1 \mu \mathrm{M}, 10 \mu \mathrm{M}, 100 \mu \mathrm{M}$ ) for 24 hours. After that time 20 randomly chosen images were taken in confocal microscope to assess the number of cell-in-cell structures in each experimental group

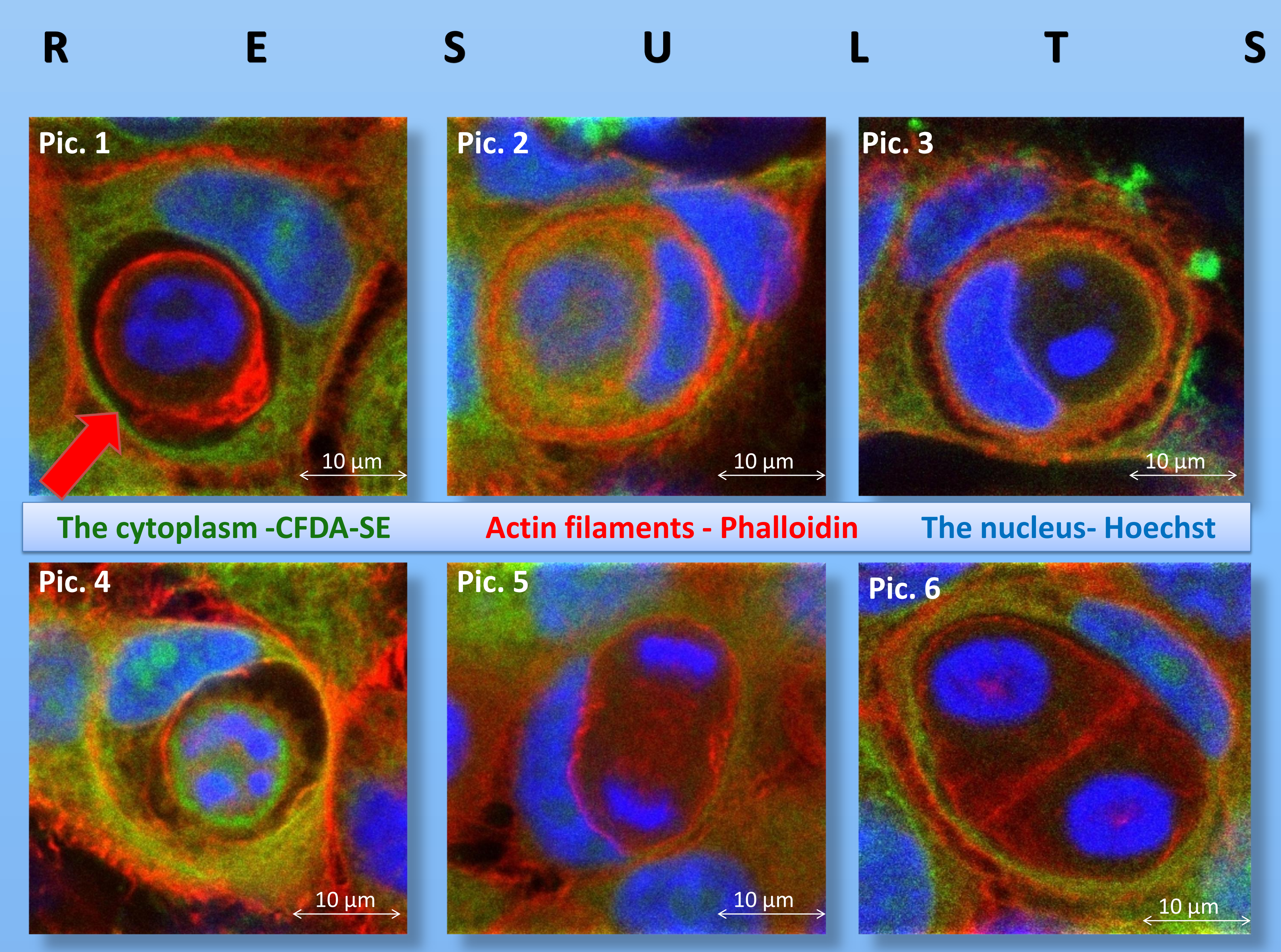

Pictures 1-6. Different cell-in-cell stuctures. Pictures from confocal microscope

\section{Pic. 1. Cell-in-cell structure. Red arrow indicates inner cell. Pic. 2. Cell-in-cell-in-cell.} Pic. 3. Apoptosis in inner cell.
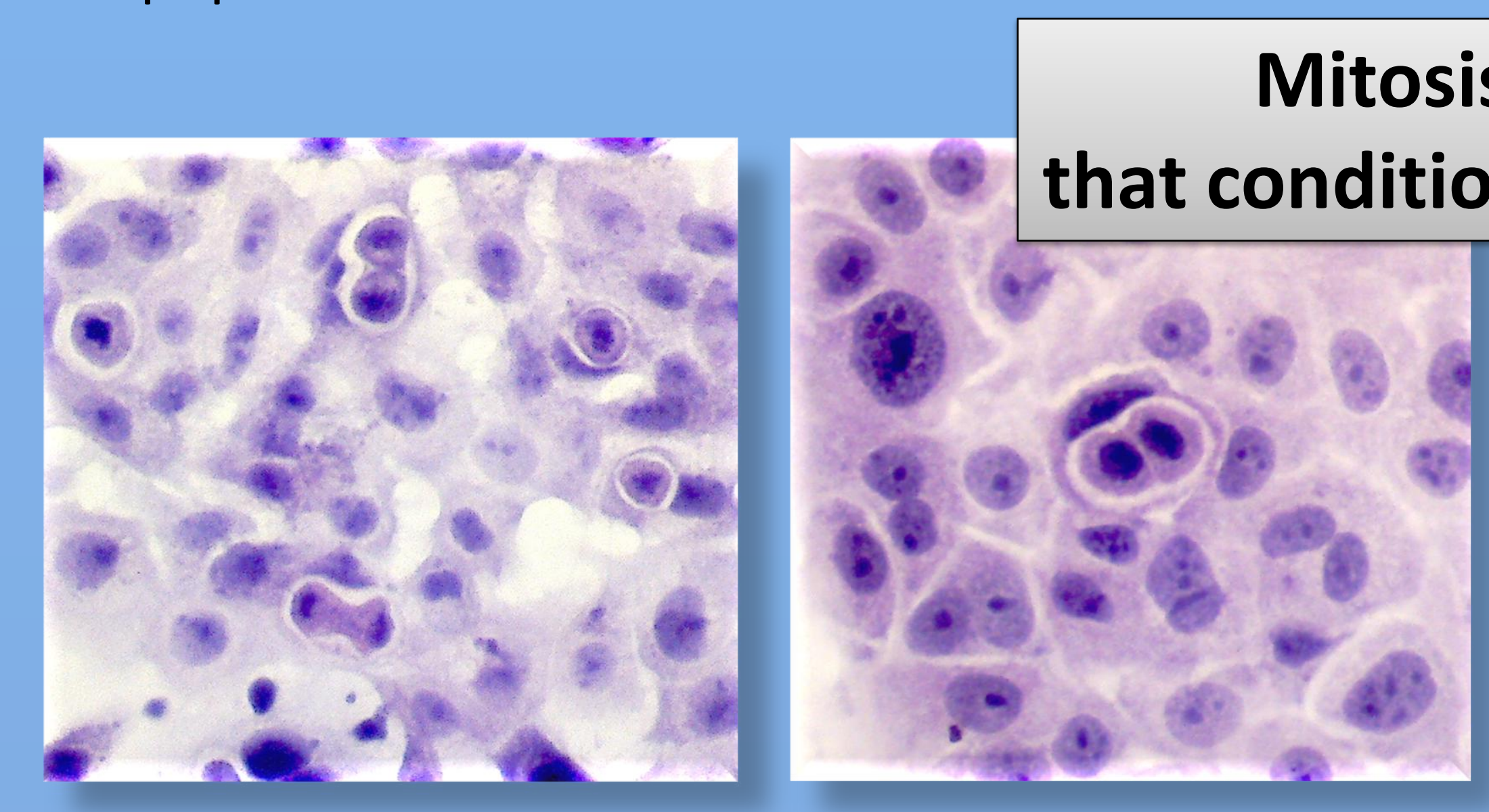

Mitosis in inner cell proves

Pictures 7-9. Mitosis in inner cells. Pictures from optical microscope

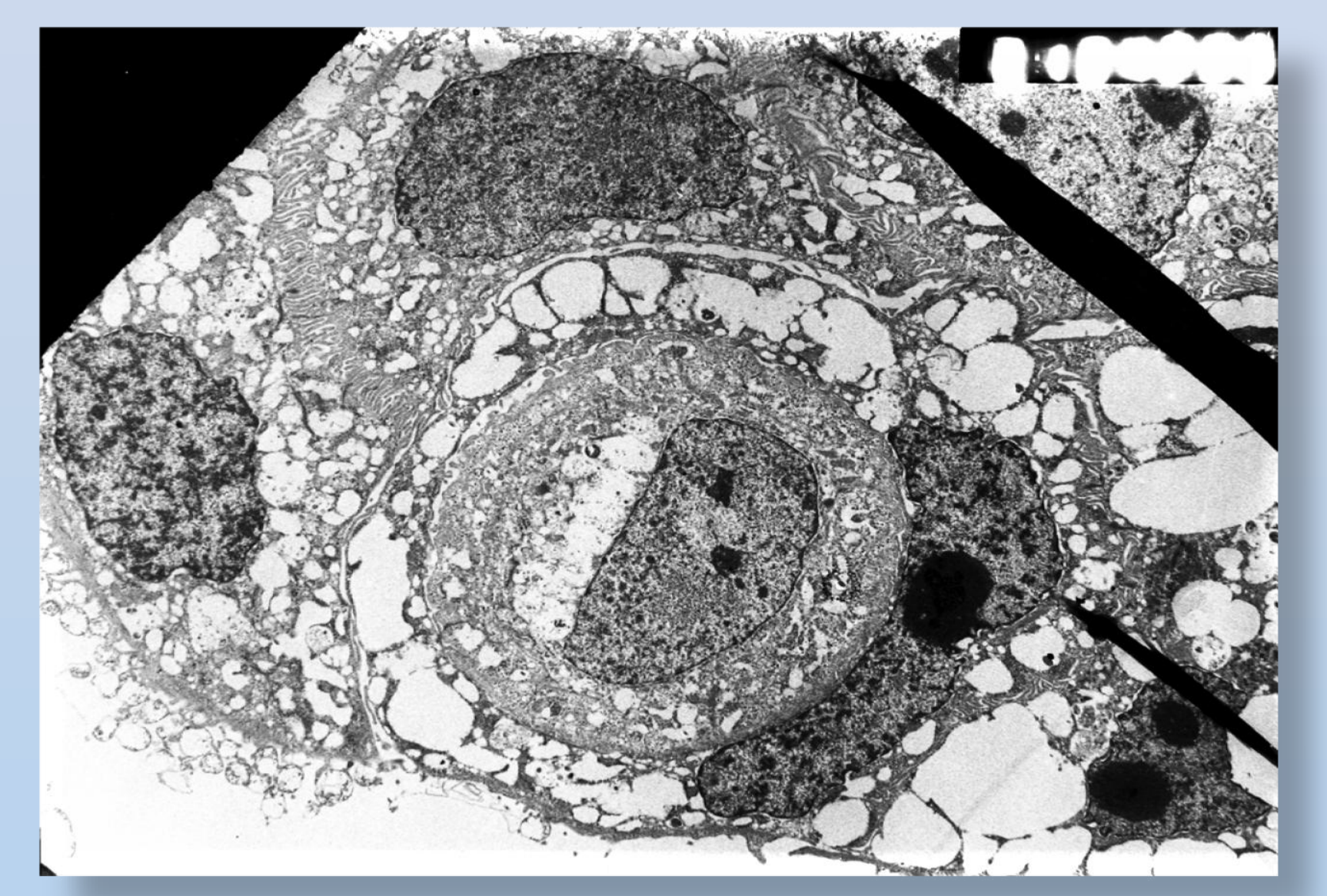

Pic. 10. BxPC3 cells. Picture obtained from electron microscope

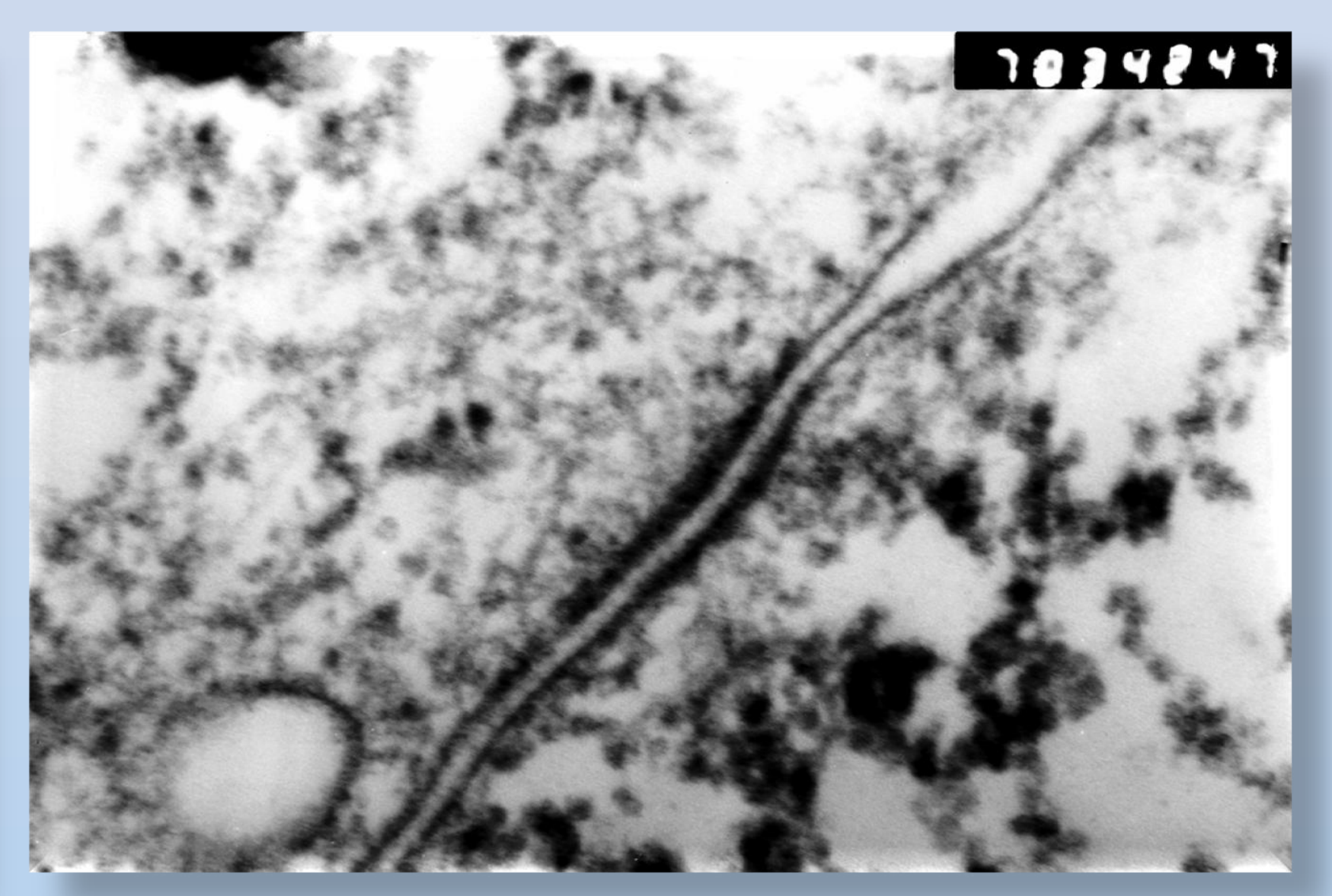

Pic. 11. Adherens junction between cells during entosis

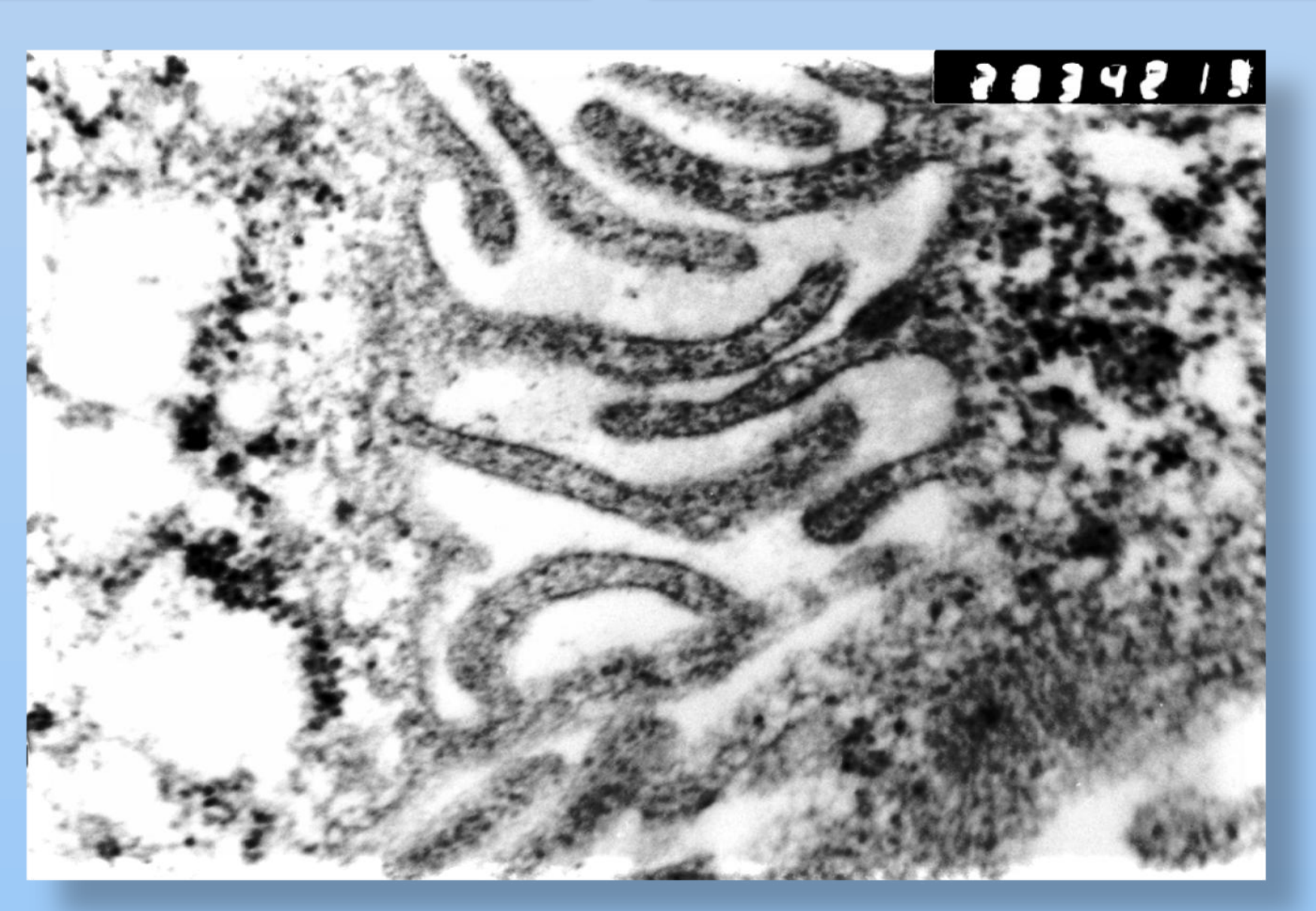

S

Pic. 12. Cytoplasmic projections at the interface of cells during interphase

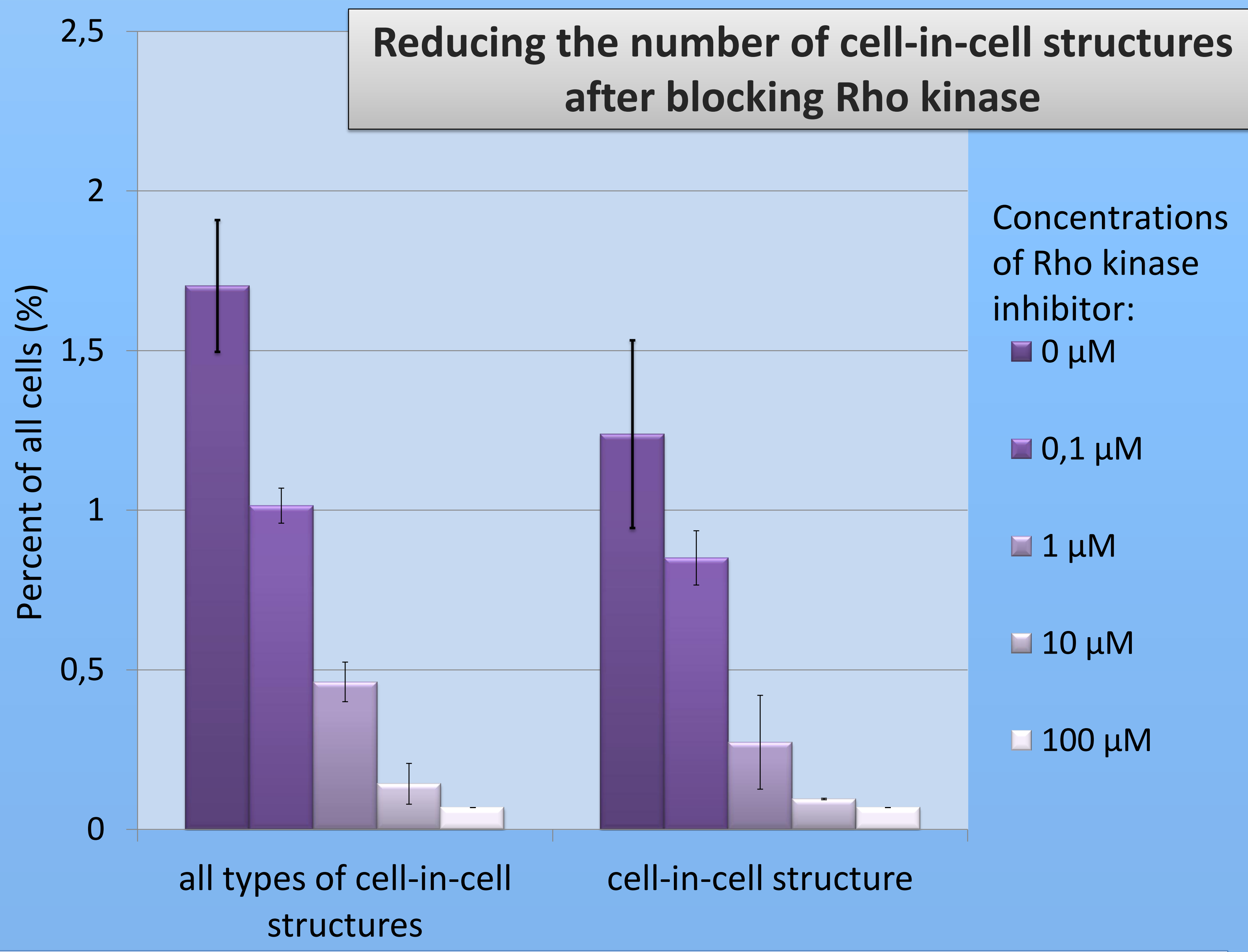

Graph 1. Effect of Rho kinase inhibitor on the number of cell-in-cell structures after 24 hours of incubation

$\begin{array}{lllllllllll}C & \mathbf{O} & \mathbf{N} & \mathrm{C} & \mathrm{L} & \mathbf{U} & \mathrm{S} & \mathbf{I} & \mathbf{O} & \mathbf{N} & \mathbf{S}\end{array}$

Most of inner cells within "cell in cell" structures demonstrated no signs of damage (like blebbing, chromatin condensation, membranes rupture). Moreover mitotic figures were visible in some entotic structures and it's providing that the inner cell is in good condition. Rho kinase inhibitor decreases number of entotic cells. Activation of Rho kinase pathway and formation of adherens junctions are involved in creating cell-in-cell structures among BxPC3 pancreatic cancer cells suggesting that this is entosis rather than cannibalism.

\section{A $\quad \mathbf{T} \quad \mathbf{U} \quad \mathbf{R} \quad \mathbf{E}$}

1)Cell. 2007 Nov 30;131(5):966-79. A nonapoptotic cell death process, entosis, that occurs by cell-in-cell invasion. Overholtzer M, Mailleux AA, Mouneimne G, Normand G, Schnitt SJ, King RW, Cibas ES, Brugge JS.

2) EMBO Mol Med. 2012 Sep 4(9):964-79. Homotypic cell cannibalism, a cell-death process regulated by the nuclear protein 1, opposes to metastasis in pancreatic cancer. Cano CE, Sandí MJ, Hamidi T, Calvo EL, Turrini O, Bartholin L, Loncle C, Secq V, Garcia S, Lomberk G, Kroemer G, Urrutia R, lovanna JL 